Article Type: Research Paper

\title{
TAX AND ECONOMIC GROWTH IN NIGERIA: AN ARDL APPROACH
}

\author{
Justine Tochukwu Nwanakwere
}

\begin{abstract}
This study investigates the relationship between tax and economic growth (GDP) using the Auto-Regressive Distributed Lag (ARDL) bound test approach. The study further decomposed tax into company income tax (CIT), petroleum profit tax (PPT), value-added tax (VAT) and excise and custom duties (ECD), then examined the effect of each of them on economic growth. The data for the study were obtained from Federal Inland Revenue Service (FIRS) and Central Bank of Nigeria (CBN) bulletin, spanning from 1981-2014. The ARDL results show no cointegration among the variables. Interestingly, the short run results reveal that total tax is insignificant while the decomposed taxes are significant. Petroleum profit tax and value-added tax have positive relationship with GDP while company income tax and excise and custom duties have negative relationship with GDP. From these findings, the study recommends an effective use of taxation so as to improve the impact of tax on the Nigerian economy. Also, efficient tax regulation should be put in place to mitigate the issue of tax evasion, especially among firms and corporate entities, and improve the contribution of CIT to economic growth.
\end{abstract}

Keywords: Tax; ARDL; Economic Growth; Taxation.

JEL Classification: $\mathrm{G} 1 ; \mathrm{H} 2 ; \mathrm{H} 7 ; \mathrm{H} 24$.

Nwanakwere, J. T. (2019). Tax and

Economic Growth in Nigeria: An

ARDL Approach. Jurnal Ekonomi \&

Studi Pembangunan, 20(2), 124-

134.

\section{ARTICLE HISTORY}

Received:

19 June 2019

Accepted:

29 September 2019

\section{Introduction}

The economic history of both developed and developing countries reveals that tax is an indispensible instrument in the hand of government; not only as revenue source, but also as a fiscal policy measure for economic stabilization. Tax plays a vital role in economic development of a country which includes: resource mobilization, reduction in inequalities of income, improvement in social welfare, foreign exchange, regional development, inflation control, etc (Arisoy \& Unlukaplan, 2010). According to the classical economists, the only objective of taxation was to raise government revenue (Dahlby, 2003), but with the progression of knowledge and ideologies, the aim of taxes has also evolved. Aside the fundamental role of public revenue generation by tax, it affects income level of a consumer, consumption level and pattern, production and distribution pattern. Hence, the change in paradigm implies that tax can serve as a tool in allocating available resources, raising government revenue, encouraging savings and investment, accelerating economic growth, price stability, and control mechanism (Emran \& Stiglitz, 2005). 


\author{
Nwanakwere \\ Tax and Economic Growth in Nigeria: An ARDL Approach
}

Tax is a compulsory levy imposed on a subject or upon his property by the government to provide security, social amenities and to create conditions for the economic wellbeing of the society (Appah \& Oyandonghan, 2011). Anyanwu (1997) defined tax as compulsory transfer or payment from private individuals, institutions or groups to the government. In view of Jarkir (2011), tax is a contribution enacted by the state; it is non-penal but compulsory and unrequited transfer of resources from the private to the public sector, levied on the basis of predetermined criteria (Jarkir, 2011). Thus, tax can be said to be a compulsory levy paid by individuals and corporate bodies as stipulated by the tax law which serves as revenue to the government.

Taxes are crucial elements of the economy and they determine changes in national income and other macroeconomic variables, especially in developing countries like Nigeria. Increased taxation on imported goods and services has considerable effect on production level of such goods and services produced by local manufacturers. Consequently, an efficient and effective tax administration results in increased revenue yield. However, poor fiscal discipline in the allocation of resources as well as the implementation of ineffective tax regime in Nigeria become a major challenge (Garba, 2014).

Over time, studies have been carried out on the empirical relationship between tax and economic growth, both in the developed and the developing nations (Kyle, 2018; Saibu, 2015; Ahmad \& H.Sial, 2016). The outcome of the studies has shown conflicting empirical results as to whether tax brings about economic growth or otherwise.

In a study by Wambai and Hanga, (2013) on taxation and social development in Nigeria, they found that the attitude of the government on taxation need to change and recommends a tax system that concentrate on establishing simplicity, predictability, and neutrality. Simwaka, Munthali, Kabango, and Chiumia (2012) studies analyses the effect of taxation in sub-Saharan Africa. They found that taxes levied on personal and corporate income reduces economic growth. From their study, one may be tempted to conclude that the tax structure is largely irrelevant in less developed economies, but embedded in an effective tax system are benefits for both the taxpayers and the government.

Tosun and Abizadeh (2005) studied economic growth and tax charges in OECD countries from 1980 to 1999; their study reveals that economic growth measured by GDP per capita has significant effect on tax mix of GDP per capita. The study recorded a decline in shares of payroll, goods and services and positive growth from personal and property taxes.

Olusanya, Medunoye, and Oluwatosin, (2012) investigated taxation as a fiscal policy instrument for income redistribution among Lagos state civil servants using spearman's rank correlation coefficient. The study found a positive relationship between tax as fiscal policy instrument and income redistribution. In the study on taxation and economic growth of the United States, Engen and Skinner (1996) found a modest effect on the order of 0.2 to 0.3 percentage point increase in growth rates in response to major tax reform. Their findings suggest that such minor effect cumulatively can have large impact on the standards of living. 


\author{
Nwanakwere \\ Tax and Economic Growth in Nigeria: An ARDL Approach
}

In Nigeria, different types of taxes are being imposed over time on the various economic agents (Margaret, 2014). The primary purpose is to generate revenue for the government which in turn should be used to provide social amenities and achieve economic growth. However, it is also of a great debate as to whether tax has contributed to the economic growth of the country or not. Besides, this study chose to adopt the ARDL bound test for its estimation of cointegration rather than the conventional Johansen and OLS estimation techniques.

Consequently, this study seeks to empirically examine the impact of tax on economic growth in Nigeria. Besides, the study is extended by disaggregating tax into company income tax (CIT), petroleum profit tax (PIT), value-added tax (VAT), and excise and custom duties (ECD) and evaluates their individual impacts on economic growth in the country. In relation to this effect, the study begins by asking questions like: what is the relationship between tax and economic growth in Nigeria? Do any of the individual taxes contribute to economic growth in Nigeria? Answers to these questions will help in achieving the objectives of the study. This study is organized into five sections starting with the introduction, followed by review of literature, theoretical construct and methodology, results and discussion, and conclusion and policy recommendation in that order.

\title{
Research Method
}

\section{Theoretical Construct}

The neoclassical growth model of Solow reveals the basic theoretical linkage between tax and economic growth. In the growth model, output of an economy is determined by the size and skill of labour and the size and technological productivity of its capital stock (Engen and Skinner, 1996). Therefore, the growth rate of output will depend on the growth rate of capital stock - both physical and human capital - and changes in productivity of these inputs in the economy. The growth rate of the economy can be stated as:

$$
\dot{G}_{\boldsymbol{\imath}}=\propto \dot{K}+\boldsymbol{\beta} \dot{L}+\dot{\forall}
$$

where the economic growth rate of country $\boldsymbol{i}$ is $\dot{\boldsymbol{G}}, \dot{\boldsymbol{K}}$ and $\dot{\boldsymbol{L}}$ are change in capital stock (net investment) and growth rate in effective labour force, respectively, $\dot{\forall}$ measures productivity growth, while $\propto$ and $\boldsymbol{\beta}$ are marginal productivity of capital and output elasticity of labour, respectively.

Engen and Skinner (1996) stated that the neoclassical growth theoretical framework gives insight into the connection between tax and economic growth through the variables on the model above. Hence, they argued that higher taxes can discourage the investment rate, or the net growth in the capital stock, through high statutory tax rates on corporate and individual income and high effective capital gains tax rates. Besides, taxes may discourage labour force participation and affect skills, trainings and educational attainment which in turn weaken labour supply growth. In addition, tax policy can affect 
productivity growth rate by discouraging research and development (R\&D), and reduce marginal productivity of capital by discouraging investment in productive heavily taxed sectors into less taxed sectors with low productivity (Engen and Skinner, 1996).

\section{Methodology}

This study adopted the Auto-Regressive Distributed Lag (ARDL) model bound testing approach (Dickey \& Fuller, 1979). This method helps to take care of the problem of drifting series and equally enables us to determine both the short run and the long run relationship of the model (Ahmed, Zaman, \& Syah, 2011). The ARDL approach, developed by Pesaran, Shin, \& Smith (2001), was chosen over the conventional Engle and Granger (1987) and Johansen and Juselius (1990) approach for long run test (cointegration) as a result of its advantages over them. The ARDL approach can be applied to series that are both of the same order and of different order of integration i.e. I(0) or I(1) series, or combination of I(0) and I(1) series; unlike the other techniques (Ahmad, 2016). Besides, Haug (2002) pointed out that ARDL bounds testing approach is more suitable and provides better results for small sample size, and the short and long-run parameters are estimated simultaneously.

The study identified both dependent variable (economic growth measured by the GDP) and independent variable which is tax. It focuses on the impact of total tax on economic growth, and by extension, examines the individual impacts of the disaggregated taxes (CIT, PPT, VAT and ECD) on economic growth. Thus, GDP depends on total tax generated within the period under study and also on the disaggregated individual taxes (CIT, PPT, VAT and ECD). Hence, we established two separate models for the study.

In terms of functional relationship, we have them stated as;

$$
\begin{aligned}
G D P & =f(T A X) \\
G D P & =f(C I T, P P T, V A T, E C D)
\end{aligned}
$$

Mathematical representations of the functions are stated as;

$$
\begin{array}{ll}
\text { GDP } & =\beta_{0}+\beta_{1} T A X+\varepsilon \\
G D P & =\beta_{0}+\beta_{1} C I T+\beta_{2} P P T+\beta_{3} V A T+\beta_{4} E C D+v
\end{array}
$$

Where:

$$
\begin{array}{ll}
\text { GDP } & =\text { Gross domestic product; } \\
\text { TAX } & =\text { Tax (aggregated tax); } \\
\text { CIT } & =\text { Corporate income tax; } \\
\text { PPT } & =\text { Petroleum profit tax; } \\
\text { VAT } & =\text { Value-added tax; } \\
\text { ECD } & =\text { Excise and custom duties; } \\
\varepsilon, v & =\text { error terms. }
\end{array}
$$

$\beta_{0}, \beta_{1}, \beta_{2}, \beta_{3}$, and $\beta_{4}$, are parameters which serve as coefficients of the estimators defined above in the models. 
The cointegration relationship among variables of the model specified in equations (4) following the ARDL equation is stated as:

$$
\begin{aligned}
& \Delta \log (G D P)_{t}=\varnothing+\varphi_{1} \log (G D P)_{t-1}+\varphi_{2} \log (C I T)_{t-1}+\varphi_{3} \log (P P T)_{t-1}+ \\
& \varphi_{4} \log (V A T)_{t-1}+\varphi_{5} \log (E C D)_{t-1}+\sum_{i=1}^{p} \gamma_{i} \log (G D P)_{t-1}+\sum_{i=1}^{p} \theta_{i} \log (C I T)_{t-1}+ \\
& \sum_{i=1}^{p} \delta_{i} \log (P P T)_{t-1}+\sum_{i=1}^{p} \mu_{i} \log (V A T)_{t-1}+\sum_{i=1}^{p} \sigma_{i} \log (E C D)_{t-1}+\varepsilon_{t}
\end{aligned}
$$

$\boldsymbol{p}$ is the ARDL model maximum lag order. The coefficients of the lagged variables represent the long run relationship, while the coefficients of the summations represent the short run model. The F-test is carried out on the joint null hypothesis that the coefficients of the lagged variables are zero (Nkoro \& Uko, 2016). The hypothesis states that the coefficients of the lag level variables are zero i.e., there are no long run relationships among the series. This is defined by:

$$
\begin{aligned}
& \mathrm{H}_{0}: \varphi_{1}=\varphi_{2}=\varphi_{3}=\varphi_{4}=\varphi_{5}=0 \text { (long run relationship does not exist) } \\
& \mathrm{H}_{1}: \varphi_{1} \neq \varphi_{2} \neq \varphi_{3} \neq \varphi_{4} \neq \varphi_{5} \neq 0 \text { (long run relationship exist) }
\end{aligned}
$$

\section{Sources of Data}

Data for the study was obtained from the Federal Inland Revenue Service (FIRS), Nigeria Bureau of Statistics (NBS), and Central Bank of Nigeria (CBN) Statistical Bulletin. The FIRS have the statutory authority of tax revenue collection in the Nigeria. The data spanned from 1981 to 2014. However, VAT which was initiated in 1994 has some missing data. Before the introduction of VAT, sales tax was levied at retail, wholesale, and private final consumption levels, which was later officially replaced by VAT. Many authors have suggested that sales tax can be used to fill up for the missing data (Ekeocha, Ekeocha, Malaolu, \& Oduh, 2012).

\section{Result and Discussion}

Various preliminary tests such as descriptive statistics, diagnostic tests (Breusch-Goddfrey Serial Correlation LM test, Glejser Heteroskedasticity test, Ramey RESET tests) were carried out as well as unit root test using the Augmented Dicky-Fuller (ADF) unit root test (see Table 1). GDP is stationary at first difference while tax in aggregate is stationary at level. On the other hand, the individual taxes are stationary at the combination of both level and first difference $\mathrm{I}(0)$ and $\mathrm{I}(1)$. The credibility of the series, cointegration and hypotheses were tested through the autoregressive regressive distributive lag (ARDL)/bound test. Firstly, we analyzed the relationship between aggregated tax and economic growth, after which we analyzed relationships between various individual taxes (CIT, PPT, VAT, and ECD) and economic growth (GDP). 
Table 1 Summary of Unit Root Test Result

\begin{tabular}{ccccc}
\hline Variables & Level & Fugmented Dicky-Fuller (ADF) & \\
\hline GDP & 2.339251 & $-6.633529^{* *}$ & Critical value (5\%) & I(d) \\
\hline TAX & $-5.817870^{*}$ & & -3.552973 & $\mathrm{I}(1)$ \\
CIT & -1.404865 & $-6.137964^{* *}$ & -2.960410 & $\mathrm{I}(0)$ \\
VAT & $-5.204487^{*}$ & & -3.552973 & $\mathrm{I}(1)$ \\
PPT & -3.543251 & $-5.861270^{* *}$ & -3.658446 & $\mathrm{I}(0)$ \\
ECD & -1.476805 & $-5.242427^{* *}$ & -3.552973 & $\mathrm{I}(1)$ \\
\hline
\end{tabular}

Note: * significant at level, **significant at first difference

Source: Authors' computation

\section{Autoregressive Distributed Lag (ARDL) Model Result}

The ARDL bounds test is always stated in the null hypothesis form which means that there is no cointegration among the variables. Thus the decision rule is such that if the $\mathrm{F}$ Statistics value is greater than the upper bound critical values, we reject the null; and if less than the lower bound critical values, we do not reject the null. If the F-Statistics is between upper and lower bounds critical values, the result becomes inconclusive.

Tables 2 and 3 show that there is no cointegration among the variables as the F-statistics values in the two results are less than the lower bound at different significance level. Here, there is no long run relationship between total tax and GDP, and there is no long run relationship between the individual taxes (company income tax, petroleum profit tax, value added tax, and excise and custom duties) and GDP. Hence, we proceed to estimate the short run models.

Table 2 Summary of ARDL Bounds Test for Cointegration of Aggregate Tax and GDP

\begin{tabular}{lll}
\hline Variables & F-Statistics & Cointegration \\
\hline F(GDP,TAX) & 1.54 & \\
Critical value & Lower Bound & Upper Bound \\
$1 \%$ & 8.74 & 9.63 \\
$2.5 \%$ & 6.56 & 7.3 \\
$5 \%$ & 5.59 & 6.26 \\
\hline
\end{tabular}

Source: Authors' computation

Table 3 Summary of ARDL Bounds Test for Cointegration of individual Taxes and GDP

\begin{tabular}{lll}
\hline Variables & F-Statistics & Cointegration \\
\hline F(GDP,CIT, PPT, VAT, ECD) & 3.20 & \\
Critical value & Lower Bound & Upper Bound \\
$1 \%$ & 4.40 & 5.72 \\
$2.5 \%$ & 3.89 & 5.07 \\
$5 \%$ & 3.47 & 4.56 \\
\hline
\end{tabular}

Source: Authors' computation 


\section{Short Run Estimate of Aggregate Tax}

Table 4 Summary of Short Run Estimate of ARDL Test (aggregate Tax)

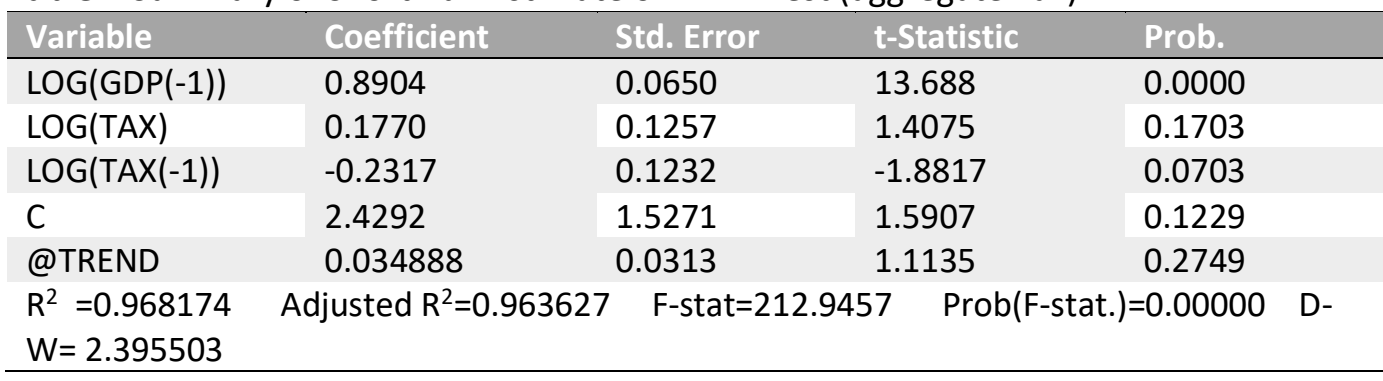

Source: Author's computation

Table 4 shows that tax in the current period has a positive relationship with GDP, while tax in the previous periods has a negative with GDP. This implies that current tax does contributes to economic growth than previous tax in the economy. However, the result also shows that tax in the current period is not significant, while tax in previous period is significant.

\section{Short Run Estimate of Individual Taxes}

Table 5 Summary Short Run Estimate of ARDL Test (individual Taxes)

\begin{tabular}{lllll}
\hline Variable & Coefficient & Std. Error & t-Statistic & Prob. \\
\hline LOG(GDP(-1)) & -0.3178 & 0.2043 & -1.5554 & 0.142 \\
LOG(CIT) & -0.8385 & 0.3265 & -2.5675 & 0.022 \\
LOG(PPT) & 0.1445 & 0.0516 & 2.7964 & 0.014 \\
LOG(VAT) & 1.4285 & 0.3085 & 4.6299 & 0.000 \\
LOG(ECD) & -1.0797 & 0.1961 & -5.5047 & 0.000 \\
C & 30.53049 & 4.6477 & 6.568925 & 0.000 \\
$R^{2}=0.992614$ & Adjusted R $R^{2}=0.989449$ & F-stat=313.5925Prob(F-stat.) $=0.00000$ \\
D-W $=2.290476$ & & & & \\
\hline
\end{tabular}

Source: Author's computation

Table 5 shows ARDL short run result for the individual taxes: company income tax (CIT), petroleum profit tax (PPT), value added tax (VAT), and excise and custom duties (ECD), and GDP. It is observed from the R-square value that 98 percent of the change in GDP is attributed to the various taxes; hence the model is good for estimation and prediction. The value of the Durbin-Waston statistics is greater than 2, which signifies that the residuals of the model are uncorrelated. The table further shows that all the variables are significant with the exception of one lag value of GDP. PPT and VAT have positive relationship with GDP while CIT and ECD have negative relationship with GDP. Based on the magnitude of the coefficients, it is observed that VAT has the highest value with 1.42, while PPT records the lowest with 0.14 . This implies that VAT contributes the highest to economic growth in Nigeria while PPT contributes the lowest. This result supports the findings in the Federal Inland Revenue Service report that VAT contributes the most to tax revenue and economic growth among other taxes in Nigeria (FIRS, 2018). 


\author{
Nwanakwere \\ Tax and Economic Growth in Nigeria: An ARDL Approach
}

$H_{0} 1$ : Company income tax has no significant impact on economic growth:

Table 5 reveals that CIT is significant at 5 percent level; hence we reject the null hypothesis. Given the negative coefficient of -0.84 for CIT, 1 percent increase in company income tax will lead to a fall in GDP by 0.84 percent. The negative impact could be as a result of weak infrastructures that affect ease of doing business in the country (Chigbu, Akujuobi, \& Ebimobowei, 2012). Companies and firms, therefore, struggle to break-even to keep up with tax payment thus; tax evasion becomes inevitable, especially at the slightest increase. Also, tax is a disincentive to investors; therefore, increase in company income tax would lead to fall in investment which affects the growth of the economy (Otu \& Adejumo, 2016).

\title{
$H_{0} 2$ : Petroleum profit tax does not have significant impact on economic growth:
}

Petroleum profit tax records a positive relationship with GDP at 5 percent level of significance. This suggests that we reject the null hypothesis, thereafter, concluding that PIT has positive significant impact on economic growth in Nigeria. Despite the positive impact of PIT on the economy, it is observed that the magnitude (0.14) is very low compared to VAT. This means that 1 percent increase in PIT will increase economic growth by 0.14 percent.

\section{$H_{0} 3$ : Value-added tax has no significant impact on economic growth:}

The result further shows that value-added tax contributes significantly the most to economic growth in Nigeria; hence, the null hypothesis is rejected. A percentage increase in VAT will increase GDP by 1.42 percent. The reason for this could be attributed to the fact that VAT is an indirect tax which the consumers are the ultimate payers. Most people pay this tax without the knowledge of it. Hence, it is easy to collect and cases of avoidance and evasion cannot be feasible. Besides, Nigeria is more of a consuming nation with population of over 180 million people (Wambai \& Hanga, 2013). Therefore, VAT, which is a consumption-based tax, is a major revenue generation tax component which drives the economy. This is in line with finding of Egbunike, Emudainohwo, and Gunardi, (2018).

$H_{0} 4$ : Excise and custom duties have no significant relationship with economic growth:

In addition, Table 5 shows that Excise and custom duties (ECD) have negative relationship with economic growth, with significance level of 1 percent. Also, the magnitude of its coefficient is 1.08; hence, a percentage increase in ECD will decrease GDP by 1.08 percent. This could be caused by the weak industrial base and the less productive manufacturing sector which contributed only about 9 per cent to GDP in 2018 (CBN, 2018). Besides, as mentioned earlier in the case of company income tax, producers tend to avoid and evade tax. As a result of their low production capacity and high cost of business operation in the country, any attempt to increase excise and custom duties will threaten the existence of many industries, affecting the GDP negatively. Furthermore, high level of corruption among the agencies contributes to the negative impact on the economy (Edame \& Okoi, 2014). 


\section{Conclusion}

The result from the study reveals that total tax has a positive impact on economic growth; however, the impact is not substantial. Hence, we conclude that aggregate tax has not contributed significantly to the economic growth of the country. In contrast to this result, the study shows that the disaggregated taxes are all significant. While petroleum profit tax and value-added tax have positive impact on economic growth in Nigeria, company income tax and excise and custom duties have negative impact on economic growth. Value-added tax and petroleum income tax respond positively as a result of the nature of tax of the former (indirect tax), which is levied on goods and services, and payers, most times, are not aware of their paying it. Revenue generated from these taxes is always massive as a result of the dynamism of the sectors (especially the oil sector), and the difficulty to avoid or evade as in the case of value-added tax.

\section{Recommendation}

From these findings, we make the following recommendations: (1) There should be fiscal discipline and effective use of tax revenue by the government to achieve macroeconomic growth in the economy. (2) Tax administration should be organized in such a way that makes it effective and efficient; hence, curbing tax evasion and avoidance. (3) Government should monitor and moderate company income tax so as to encourage investors into the country which would lead to CIT contributing to economic growth in the country. (4) Government should diversify the economy from a single sector (oil) to multiple sectors in order to increase the capacity base of the country; hence, generating more revenue and contributing to growth.

\section{References}

Ahmad, S., \& H.Sial, M. (2016). Taxes and Economic Growth: An Empirical Analysis of Pakistan. European Law Review 8(6), 18-33. https://doi.org/10.21859/eulawrev$\underline{08062}$

Ahmed, J., Zaman, K., \& Shah, I. A. (2011). An Empirical Analysis of Remittances-Growth Nexus in Pakistan Using Bounds Testing Approach. Journal of Economics and International Finance. 3(3), 176-186. Retrieved from: https://academicjournals.org/journal/JEIF/article-abstract/6AE346E4733

Anyanwu, J. C. (1997). Nigeria Public Finance. Joance Education Publishers, Onitsha. Appah, E. \& Oyandonghan, J. K. (2011). The challenges of tax mobilization and management in the Nigerian economy. J. Bus. Admin. Manage., 6(2): 128-136.

Arisoy, I., \& Unlukaplan, I. (2010), Tax Composition and Growth in Turkey: An Empirical Analysis. International Research Journal of Finance and Economics. 59(9), 51 - 61.

Central Bank of Nigeria. (2019). Annual Report 2019.

Chigbu, E. E., Akujuobi, L. E., \& Ebimobowei, A. (2012). An Empirical Study on The Causality Between Economic Growth and Taxation in Nigeria. Journal of Economic Theory. 4(2), 29-38. 


\section{Nwanakwere \\ Tax and Economic Growth in Nigeria: An ARDL Approach}

Dahlby, B. (2003). Restructuring the Canadian Tax System by Changing the Mix of Direct and Indirect Taxes. In H. G. Resource Allocation and Welfare, in 'NBER' and the Brookings Institution, Princeton: Princeton University Press 25 - 75.

Dickey, D. A., \& Fuller, W. A. (1979). Distribution of the Estimators for Autoregressive Time Series with a Unit Root. Journal of the American Statistical Association. 74(366), 427-731. https://doi.org/10.2307/2286348

Edame, G. E., \& Okoi, W. W. (2014). The Impact of Taxation on Investment and Economic Development in Nigeria. Academic Journal of Interdisciplinary Studies. 3(4), 209-218. https://doi.org/10.5901/ajis.2014.v3n4p209

Egbunike, F. C., Emudainohwo, O. B., \& Gunardi, A. (2018). Tax Revenue and Economic Growth: A Study of Nigeria and Ghana. Signifikan: Jurnal Ilmu Ekonomi. 7(2), 213 220. https://doi.org/10.15408/sjie.v7i2.7341

Ekeocha, P. C., Ekeocha, C. S., Malaolu, V., \& Oduh, M. O. (2012). Revenue Implications of Nigeria'S Tax System, Journal of Economics and Sustainable Development, 3(8), 206215. Retrieved from: https://www.iiste.org/Journals/index.php/JEDS/article/view/2321/2322

Emran, M. S., \& Stiglitz, J. E. (2005). On Selective Indirect Tax Reform in Developing Countries. Journal of Public Economics. 89(4), 599-623. https://doi.org/10.1016/i.jpubeco.2004.04.007

Engen, E. M. \& Skinner, J. (1996). Taxation and Economic Growth. NBER Working Paper. National Bureau of Economic Research, Cambridge. https://doi.org/10.3386/w5826

Engle, R. F. \& Granger, C. W. J. (1987). Cointegration and Error Correction Representation: Estimation and Testing. Econometrica. 55(2), 251-276. https://doi.org/10.2307/1913236

Federal Inland Revenue Service (FIRS). (2018). Annual Report 2018, Revenue generation in Nigeria.

Garba L. S. (2014). Tax Revenue and Economic Growth. Thesis. Department of Accounting, Faculty of Administration, Ahmadu Bello University, Zaria.

Haug, A. A. (2002). Temporal Aggregation and the Power of Cointegration Tests: A Montecarlo Study. Oxford Bulletin of Economics and Statistics. 64(4): 399-412. https://doi.org/10.1111/1468-0084.00025

Jarkir, K. (2011). Role of Tax Revenue in Economic Development. Journal of Accounting and Tax Revenue. 33(55), 91-104.

Johansen, S. \& Juselius, K. (1990). Maximum Likelihood Estimation and Inference on Cointegration - with Applications to the Demand for Money. Oxford Bulletin of Economics and Statistics. 52(2), 169-210. https://doi.org/10.1111/j.14680084.1990.mp52002003.x

Kazmi, S. M. A. (2015). Real Private Consumption Expenditure ModelingAn Empirical Study on Pakistan. Journal of Economics and Sustainable Development, 6(17), 36-48. Retrieved from: https://www.iiste.org/Journals/index.php/JEDS/article/view/25801/26648

Margaret, N., Okoli, Charles, O. N, Gift, N. K. (2014). Taxation and Economic Growth in Nigeria: A Granger Causality Approach. International Journal of Research in Management, Science \& Technology. 2(3).

McNabb, K. (2018). Tax Structures and Economic Growth: New Evidence from the Government Revenue Dataset. Journal of International Development. 30(2), 173-205. https://doi.org/10.1002/jid.3345

Nkoro, E., \& Uko, A. K. (2016). Autoregressive Distributed Lag (ARDL) Cointegration Technique: Application and Interpretation. Journal of Statistical and Econometric 
Methods. 5(4), 1-3. Retrieved from:

https://ideas.repec.org/a/spt/stecon/v5y2016i4f5_4_3.html

Olusanya, S.O., Medunoye, P. \& Oluwatosin, O. A. (2012). Taxation as a Fiscal Policy Instrument for Income Redistribution among Lagos State Civil Servants. IOSR Journal of Humanities and Social Sciences. 5(5), 60-70. https://doi.org/10.9790/0837-0556070

Otu, H. B. \& Adejumo, T. O. (2013). The effects of Tax Revenue on Economic growth in Nigeria $(1970$ - 2011). International Journal of Humanities and Social Science Invention. 2(6), 16-26. Retrieved from: https://www.academia.edu/20772705/The Effects of Tax_Revenue on Economic Growth in Nigeria 1970-2011

Pesaran, M. H., Y. Shin, Y., \& Smith, R. J. (2001). Bounds testing approaches to the analysis of level relationships. Journal of Applied Econometrics. 16(3), 289-326. https://doi.org/10.1002/jae.616

Saibu, O. M. (2015). Optimal Tax Rate and Economic Growth. Evidence from Nigeria and South Africa. Euro Economica. 34(1), 41-50. Retrieved from: http://journals.univdanubius.ro/index.php/euroeconomica/article/view/2586/3117

Simwaka, K., Munthali, T., Kabango, G., \& Chiumia, A. (2012). Financial Development and Economic Growth in Malawi: An Empirical Analysis. Banks \& Bank Systems (2012). 7(3), 85-96.

Tosun, M. S., \& Abizadeh, S. (2005). Economic growth and taxcomponents: an analysisof tax changes in OECD. Applied Economics, 37, 2251-2263. Retrieved from: https://www.researchgate.net/publication/24075588 Economic growth_and tax co mponents An analysis of tax changes in OECD

Wambai, U. S. K., \& Hanga, B. Y. (2013). Taxation and Societal Development in Nigeria: Tackling Kano's Hidden Economy. International Journal of Academic Research in Business and Social Science. 3(3), 113-125. Retrieved from: https://pdfs.semanticscholar.org/4669/68c67cbc839a2efa18320746dfad3858f3a0.pdf 